\title{
MAKNA TRADISI TABUIK OLEH MASYARAKAT KOTA PARIAMAN (STUDI DESKRIPTIF INTERAKSIONISME SIMBOLIK)
}

\author{
M.A. Dalmenda ${ }^{1}$, Novi Elian ${ }^{2}$
}

\begin{abstract}
Tabuik Tradition is one of the activities conducted annually in Pariaman City. Rooted in religious values to commemorate the death of the Prophet Muhammad's grandson, Hussein. This anniversary actually takes place every 10th of Muharram Hijriyah calendar. This research uses case study observation design. Through observation techniques in the case study can be obtained detailed information or empirical information and accurate from the unit of research analysis. Tabuik ceremony represents a reflection of attitude and lifestyle of Pariaman society. Tabuik even made a tradition for the community that can not be separated from the lives of citizens Pariaman. Then, Tabuik implemented by Anak Nagari in the form of Tabuik Culture of Tabuik Meaning formed by each side. By society, tabuik serve as a venue for entertainment. By the government, tabuik serve as the agenda of touris $m$, while by urang tabuik, tabuik still used as a cultural tradition that should be preserved. The process of desacralization occurs due to the challenge of the taboo age developed in accordance with the ideology. The implementation of the tabuik has shifted considerably, but it is still maintained as a cultural tradition of the Pariaman community.
\end{abstract}

Keywords: Attitude, Lifestyle, Change, Pariaman Society, Tourism

\section{Abstrak}

Tradisi Tabuik merupakan salah satu kegiatan yang dilakukan setiap tahunnya di Kota Pariaman. Berakar pada nilai-nilai religi untuk mengenang wafatnya cucu Nabi Muhammad SAW, yaitu Hussein. Peringatan ini sejatinya berlangsung setiap tanggal 10 Muharram penanggalan Hijriyah. Penelitian ini menggunakan desain penelitian studi kasus observasi. Melalui teknik observasi pada studi kasus bisa diperoleh keterangan atau informasi empiris yang detail dan akurat dari unit analisis penelitian. Upacara Tabuik mewakili cerminan sikap dan pola hidup masyarakat Pariaman. Bahkan Tabuik dijadikan sebuah tradisi bagi masyarakat yang tidak dapat dipisahkan dari kehidupan warga Pariaman. Kemudian, Tabuik dilaksanakan oleh Anak Nagari dalam bentuk Tabuik Budaya Makna Tabuik yang terbentuk oleh masing-masing pihak. Oleh masyarakat, tabuik dijadikan sebagai ajang hiburan. Oleh pemerintah, tabuik dijadikan sebagai agenda pariwisata, sedangkan oleh urang tabuik, tabuik masih dijadikan sebagai tradisi budaya yang patut dilestarikan. Proses desakralisasi terjadi akibat adanya tantangan zaman tabuik berkembang sesuai dengan ideologinya. Pelaksanaan tabuik sudah jauh bergeser, namun masih tetap dipertahankan sebagai tradisi budaya masyarakat Pariaman.

Kata-Kata Kunci: Sikap, Pola Hidup, Perubahan, Masyarakat Pariaman, Pariwis ata.

\footnotetext{
${ }^{1}$ Penulis adalah dosen tetap Jurusan IImu Komunikasi FISIP Universitas Andalas

${ }^{2}$ Penulis adalah dosen luar biasa Jurusan IImu Komunikasi FISIP Universitas Andalas 


\section{A. PENDAHULUAN}

\subsection{Latar Belakang}

$\mathrm{T}$ radisi Tabuik merupakan salah satu kegiatan yang dilakukan setiap tahunnya di Kota Pariaman. Berakar pada nilai-nilai religi untuk mengenang wafatnya cucu Nabi Muhammad SAW, yaitu Hussein. Peringatan ini sejatinya berlang sung setiap tanggal 10 Muharram penanggalan Hijriyah.

Berlangsungnya ritual Tabuik tersebut tidak terlepas dari dukungan berbagai pihak, tidak terkecuali pemerintah. Namun, akhir-akhir ini pelaksanaan Tabuik sendiri seperti menjadi event pariwisata pemerintah Kota Pariaman. Tabuik tidak hanya sebagai peringatan wafatnya cucu nabi, tapi menjadi sebuah event pariwisata yang pelaksanaannya sudah mengalamai sedikit pergeseran. Pergeseran yang dimaksud seperti pelaksanaannya yang tidak hanya tanggal 10 Muharram setiap tahunnya, tetapi diselaraskan dengan akhir minggu (weekend) pada awal muharram sehingga bisa menjaring wisatawan untuk datang ke Kota Pariaman.

Pelaksanaan Tabuik dari tahun ke tahun mulai mengalami pergeseran. $\mathrm{Pe}$ nelitian Muchtar (2016) menyebutkan adakalanya Tabuik menjadi kebanggan masyarakat karena difungsikan untuk menyalurkan ekpresi cultural dan ritual, pada sisi lain menjadi media publikmasi dan tunggangan politik bagi kelompok tertentu, dan terburuk menjadi "kambing hitam" atas instabilitas yang terjadi dalam masyarakat hingga ketidaksepahamn antara pemerintah dengan masyarakat pemilik. Selain berada pada posisi kontras itu, Tabuik juga kadangkadang dihadapkan pada situasi ambiguitas, yaitu berada pada kondisi antara disukai dan tidak disukai.

Pemaparan diatas telah menujukkan adanya pergeseran makna Tabuik sendiri oleh masayarakat dan pemerintah setempat. Terjadinya desakralisasi dari pelaksanaan ritual Tabuik tersebut menarik perhatian peneliti untuk dapat menelaah bagaimana pemaknaan Tabuik tersebut di Kota Pariaman.

Pemaknaan tersebut tidak terlepas dari proses interaksi yang berlangsung di masyarakat Pariaman. Komunikasi yang terjadi di masyarakat membentuk pemak naan sendiri terhadap ritual Tabuik.

\subsection{Rumusan Masalah}

Denelitian ini memiliki rumusan ma salah sebagai berikut :

1. Bagaimana pemaknaan masyarakat terhadap Tabuik?

2. Bagaimana proses desakralisasi yang terjadi pada ritual Tabuik?

\subsection{Tujuan \\ ujuan penelitian : \\ 1. Mengetahui pemaknaan masyarakat terhadap ritual Tabuik. \\ 2. Mengetahui proses desakrali sasi yang terjadi pada ritual Tabuik.}

\subsection{Manfaat Penelitian}

enelitian ini akan memberikan

manfaat sebagai berikut :

1. Memberikan pemahaman dan gambaran bagaimana masyarakat memaknai ritual Tabuik.

2. Adanya informasi tentang kendala dan solusi

1.5 Target Luaran pelaksanaan ritual Tabuik.

5

enelitian menghasilkan luaran seba gai berikut :

1. Informasi tentang pemaknaan Tabuik sehingga bisa dijadi kan sebagai masukan bagi instansi pemerintah dalam pelaksanaan event-event kota, khususnya di Kota Pariaman.

2. Publikasi pada jurnal nasional terakreditasi/yang memiliki ISBN.

\section{B. TINJAUAN PUSTAKA}

\subsection{Komunikasi Ritual}

$\mathrm{K}$ omunikasi mengacu pada tindakan oleh satu orang atau lebih. Yang mengirim dan menerima pesan yang terdistorsi oleh gangguan (noise) terjadi dalam suatu konteks, mempunyai pengaruh tertentu dan ada kesempatan untuk melakukan umpan balik (Devito 2011). Jika dikaji dalam komunikasi antarbudaya, komunikasi didefinisikan sebagai apa yang terjadi bila makna diberikan kepada suatu perilaku. Bila seseorang memperhatikan perilaku kita dan memberinya makna, 
komunikasi telah terjadi terlepas dari apakah kita menyadari perilaku kita atau tidak dan menyengajanya atau tidak (Porter dan Samovar 2005). Komunikasi adalah mesin pendorong proses sosial yang memung kinkan terjadinya interaksi antarmanusia dan menjadikan manusia sebagai makhluk sosial (Rivers et al. 2008).

Mulyana (2010) mengatakan suatu komunitas sering melakukan upacaraupacara berlainan sepanjang tahun dan sepanjang hidup mulai dari kelahiran, sunatan, ulang tahun, pertunangan, sira man, pernikahan hingga upacara kematian.

\subsection{Interaksionisme Simbolik}

nteraksi simbolik adalah prespektif ilmiah untuk memahami kehidupan masyarakat dan perilaku manusia. Berdasarkan pandangan ini manusia sesungguhnya adalah sosok yang aktif dan dinamis serta goal-oriented, bukan semata-mata. Interaksi simbolik adalah prespektif ilmiah untuk memahami kehidupan masyarakat dan perilaku manusia. Berdasarkan pandangan ini manusia sesungguhnya adalah sosok yang aktif dan dinamis serta goal-oriented, bukan semata-mata makhluk yang pasif dan responsif, sosok yang tidak mudah dimanipulasi dan sukar diprediksi perilaku nya (Lesmana, 2001).

Cooley (1864 - 1929) melalui perangkat yang dinamakannya "sympathetic imagination," menjelaskan bahwa seseorang diyakini dapat mengamati situasi atau melihat permasalahan dari perspektif orang lain. Hal ini dilakukan dengan menempatkan diri pribadi (self) pada posisi orang lain.

Diri-pribadi diakui sebagai pusat kesadaran manusia, terdiri atas "l" dan "Me" ("Aku" dan "Diriku"), masing-masing mewakili subyek dan obyek individu. Tiap manusia sesungguhnya memiliki banyak diri-pribadi: sebagai suami atau istri di rumah, sebagai pendidik di sekolah, sebagai anggota masyarakat dan lain-lain. Konsep "Aku" dan "Diriku" kemudian dikembangkan oleh Mead dalam teorinya interaksi simbolik (Denzin, 1992).

Jhon Dewey (1859 - 1952) yang konsepnya "meaning arises through communication", adalah seorang filosof dan pendidik yang banyak menulis tentang komunikasi. Menurut Dewey, semua pengetahuan yang dimiliki manusia diperoleh dari hasil komunikasi. Bahasa memiliki kedudukan yang begitu penting, sehingga tanpa didukung oleh sistem ekspresi yang memadai, manusia mustahil bisa saling berinteraksi dan bertindak bersama. Dari proses komunikasi manusia berupaya mencari makna (meaning) suatu obyek atau peristiwa.

Beberapa tokoh interaksionisme simbolik merumuskan beberapa prinsip dasar teori ini, yang meliputi:

1. Manusia dibekali kemampuan untuk berpikir

2. Kemampuan berpikir dibentuk oleh interaksi sosial

3. Dalam interaksi sosial manusia mempelajari arti dan simbol yang memungkinkan mereka menggunakan kemampuan berpikir mereka

4. Makna dan simbol memungkinkan manusia melanjutkan tindakan khusus dan berinteraksi

5. Manusia mampu mengubah arti dan simbol yang mereka gunakan dalam tindakan dan interaksi berdasarkan penafsiran mereka terhadap situasi

6. Manusia mampu membuat kebijakan modifikasi dan perubahan, sebagian karena kemampua mereka berinteraksi dengan diri mereka sendiri yang memungkinkan mereka menguji serangkaian peluang tindakan, menilai keuntungan, dan kerugian relatif mereka, dan kemudian memilih satu diantara serangkaian peluang itu.

7. Pola tindakan dan interaksi yang saling berkaitan akan membentuk kelompok dan masyarakat (Ritzer \& Goodman, 2007).

Di samping tiga premis dasar di atas, Muhajir dalam Endraswara (2001) menambahkan tujuh proposisi,yaitu :

(1) Perilaku manusia itu mempunyai makna dibalik yang mengejala,

(2) Kemaknaan manusia dicari sumbernya kedalam interaksi sosial,

(3) Manusia itu merumuskan proses yang berkembang secara holistik, tidak terpisahkan, tidak linier, dan tidak terduga,

(4) Pemaknaan berlaku menurut penafsiran fenomenologi, yaitu sejalan dengan tujuan, dan maksud, bukan berdasarkan mekanik,

(5) Konsep mental manusia berkembang secara dialektik, 
(6) Perilaku manusia itu wajar, kreatif dan konstruktif, bukan elementer-reaktif,

(7) Perlu menggunakan metode introspeksi simpatetik, menekankan pendekatan intuitif untuk menangkap makna.

\section{Menurut kamus komunikasi} (Effendy. 1989: 184) definisi interaksi adalah proses saling mempengaruhi dalam bentuk perilaku atau kegiatan di antara anggotaanggota masyarakat, dan definisi simbolik (Effendy. 1989: 352) adalah bersifat melam bangkan sesuatu. Simbolik berasal dari bahasa Latin "Symbolic(US)" dan bahasa Yunani symbolicos".

Salah satu kebutuhan pokok manusia adalah kebutuhan simbolisasi atau penggunaan lambang, dimana manusia adalah satu-satunya hewan yang menggu nakan lambang. (Mulyana. 2008: 92). Ernst Cassirer dalam Mulyana (2008: 92) mengatakan bahwa keunggulan manusia dari mahluk lain adalah keistimewaan mereka sebagai animal symbolicum. Menurut Kamus Besar Bahasa Indonesia (Effendy, 2001: 438), definisi interaksi adalah hal yang saling melakukan aksi, berhubungan, mempengaruhi; antarhu bungan. Dan definisi simbolis (Effendy, 2001: 1066) adalah sebagai lambang; menjadi lambang; mengenai lambang.

Interaksi simbolik menurut Effendy (1989: 352) adalah suatu faham yang menyatakan bahwa hakekat terjadinya interaksi sosial antara individu dan antar individu dengan kelompok, kemudian antara kelompok dengan kelompok dalam masyarakat, ialah karena komunikasi, suatu kesatuan pemikiran di mana sebelumnya pada diri masing-masing yang terlibat berlangsung internalisasi atau pembatinan.

Jadi, definisi umum interaksi simbolik adalah segala hal yang saling berhubungan dengan pembentukan makna dari suatu benda atau lambang atau simbol, baik benda mati, maupun benda hidup, melalui proses komunikasi baik sebagai pesan verbal maupun perilaku non verbal, dan tujuan akhirnya adalah memaknai lambang atau simbol (objek) tersebut berdasarkan kesepakatan bersama yang berlaku di wilayah atau kelompok komunitas masyarakat tertentu.

Dua akar intelektual terpenting dari karya Mead dan interaksionisme simbolik adalah filiafat pragmatisme dan behavioris me psikologis (Joas, 1985; Rock, 1979 dalam Ritzer, 2011). Pragmatisme adalah pemikiran filsafat yang meliputi banyak hal. Ada beberapa aspek pragmatisme yang memengaruhi orientasi sosiologis yang dikembangkan oleh Mead (Charon, 2000; Joas, 1993 dalam Ritzer, 2010).

Pertama, menurut pemikir pragma tisme, realitas sebenarnya tak berada "diluar" dunia nyata. Realitas "diciptakan secara aktif saat kita bertindak di dalam dan terhadap dunia rtyata" (Hewitt,1984:8; Shalin,1986). Kedua, manusia mengingat dan mendasarkan pengetahuan mereka mengenai dunia nyata pada apa yang telah terbukti berguna bagi mereka. Ada kemungkinan mereka mengganti apa-apa yang tidak lagi "bekerja". Ketiga, manusia mendefinisikan "objek" sosial dan fisik yang mereka temui di dunia nyata menurut kegunaannya bagi mereka. Keempat, bila kita ingin memahami aktor, kita harus mendasarkan pemahaman itu di atas apaapa yang sebenarnya mereka kerjakan dalam dunia nyata. Ada tiga hal yang penting bagi interaksionisme simbolik:

1) Memusatkan perhatian pada interak si antara aktor dan dunia nyata

2) Memandang baik aktor maupun dunia nyata sebagai proses dinamis dan bukan sebagai struktur yang statis

3) Arti penting yang dihubungkan kepada kemampuan aktor urttuk menafsirkan kehidupan sosial.

Mead dipengaruhi oleh behavioris me psikologis (Baldwin, 1986, 1988a, 1988b dalam Ritzer, 2011), sebuah perspektif yang juga membawanya ke arah realis dan empiris. Mead sebenarnya menyebut basis pemikirannya sebagai behaviorisme sosial untuk membedakannya dari behaaiorisme radikal dari John B. Watson (salah seorang murid Mead). Behaviorisme radikai watson (Buckley, 1989) memusatkan perhatian pada perilaku individual yang dapat diamati. Sasaran perhatiannya adalah pada stimuli atau perilaku yang mendatangkan respon.

Penganut behaviorisme radikal menyangkal atau tak mau menghubungkan proses mental tersembunyi yang terjadi di antara saat stimuli dipakai dan respon dipancarkan. Mead mengakui arti penting perilaku yang dapat diamati, tetapi dia juga merasa bahwa ada aspek tersembunyi dari perilaku yang diabaikan oteh behavioris radikal. Tetapi, karena dia menerima 
empirisme yang merupakan dasar dari behaviorisme, Mead tidak sekadar ingin berfilsafat tentang fenomena tersembunyi ini. la 1ebih berupaya mengembangkan ilmu pengetahuan empiris behaviorisme terhadap fenomena itu yakni terhadap apa yang terjadi antara stimulus dan respon (Ritzer, 2011).

Bernard Meltzer merangkum pemi kiran Mead: Menurut Mead, unit studi adalah "tindakan" yang terdiri dari aspek tersem burnyi dan yang terbuka dari tindakan manusia. Di dalam tindakan itulah semua kategori psikologis tradisional dan ortodoks menemukan tempatnya. Perhatian, persep si, imajinasi, alasan, emosi, dan sebagainya dilihat sebagai bagian dari tindakan karenanya tindakan meliputi keseluruhan proses yang tertibat dalam aktivitas manusia (Meltzer, 1964 dalam Ritzer, 2011). Mead dan behavioris radikal juga berbeda pandangan mengenai hubungan antara perilaku manusia dari perilaku binatang. Sementara behavioris radikal cenderung melihat tak ada perbedaan antara perilaku manusia dan binatang, Mead menyatakan adanya perbedaan kualitatif yang signifikan.

Kunci perbedaannya adalah bahwa manusia mempunyai kapasitas mental yang memungkinkannya menggunakan bahasa antara stimulus dan respon untuk memutuskan bagaimana cara merespon. Mead juga menunjukkan utang budinya kepada behaviorisme Watsonian dan sekaligus menjauhkan pendiriannya dari aliran itu. Mead menielaskan pendiriannya ini ketika ia menyatakanbahwa di satupihak "kita akan mendekati bidang ini (psikologi sosial) dari sudut pandang behavioristik". Di lain pihak, Mead mengkritik pendirian Watson ketika menyatakan, "Behaviorisme yang akan kita gunakan itu jauh lebih memadai daripada yang digunakan Watson" (1934/1962:2).

Charles Morris dalam pengantarnya untuk buku Mead, Mind, Self and Society, menyebutkan satu per satu tiga perbedaan mendasar antara Mead dan Watson. Pertama, Mead menganggap pemusatan perhatian Watson terhadap perilaku terlalu disederhanakan. Karena itu ia menuduh Watson merenggut perilaku keluar dari konteks sosialnya yang lebih luas. Mead ingin memperlakukan perilaku sebagai bagian kecil dari kehidupan sosial yang lebih luas. Kedua, Mead menuduh Watson takberkeinginan memperluas behaviorisme ke proses mental. Watson tak memahami proses mental dan kesadaran aktor. Mead menjelaskan: Sikap Watson adalah seperti sikap Ratu dalam kisah Alice in Wonderland.

Mead membandingkan perspektif nya dengan perspektif Watson: "perspektif saya adalah perspektif behavioristik, tetapi, berbeda dengan behaviorisme Watsonian, perspektif saya mengakui bagian tindakan yang tak dapat diamati secara eksternal" (1934/1962:8). Lebih tepat lagi, Mead memandang tugasnya adalah mengembang kan prinsip-prinsip behaviorisme Watson sehingga mencakup proses mental. Terakhir, karena Watson menolak variabel pikiran, Mead memandangnya mempunyai citra pasif tentang aktor sebagai boneka. Mead, sebaliknya, mempunyai citra yang jauh lebih dinamis dan kreatif tentang aktor dan inilah yang menyebabkannya menarik perhatian penganut interaksionis simbolik yang kemudian.

Pragmatisme dan behaviorisme, terutama dalam teori Dewey dan Mead, diajarkan ke banyak mahasiswa di Universitas Chicago, terutama pada 1920an. Mahasiswa-mahasiswa itu, di antaranya adalah Herbert Blumer, membangun interak sionisme-simbolik. Tentu saja ada teoritisi lain yang memengaruhi mahasiswa ini, dan yang terpenting di antaranya adalah Georg Simmel. Perhatian Simmel terhadap bentukbentuk tindakan dan interaksi adalah sesuai dengan, dan merupakan perluasan dari teori Meadian.

Para Ilmuwan abad 20 percaya bahwa realitas bersifat dinamis, dan ide ini bukan merupakan ide yang populer pada masa itu. Dengan kata lain, mereka mempunyai keyakinan ontologis yang berbeda dibandingkan ilmuwan terkemuka lainnya pada saat itu. Dengan kata lain, mereka memiliki keyakinan ontologis yang berbeda dibandingkan kebanyakan ilmuwan terkemuka lainnya pada saat itu. Mereka mencetuskan pemikiran mengenai muncul nya struktur sosial, dan mereka bersikeras bahwa makna diciptakan melalui suatu interaksi. Mereka merupakan aktivis-aktivis yang melihat ilmu pengetahuan sebagai sebuah cara untuk mengembangkan pengetahuan dan memperbaiki masyarakat (West dan Turner, 2008).

Interaksi simbolik lahir di dua universitas yang berbeda yaitu University of 
lowa dan University of Chicago. Di lowa, Manford Kuhn dan mahasiswanya merupakan tokoh penting dan memper kenalkan ide-ide asli dari Interaksi Simbolik sekaligus memberikan kontribusi terhadap teori ini. Selain itu, kelompok lowa mengembangkan beberapa cara pandang baru mengenai konsep diri, tetapi pendekatan mereka diangap pendekatan tidak biasa. Karenanya, kebanyakan prinsip interaksi simbolik dan berakar pada mazhab Chicago.

Mead dan Dewey merupakan teman sefakultas di Universitas Chicago. Mead mempelajari filsafat ilmu sosial, dan ia memberikan ide-ide yang membentuk inti dari Mazhab Chicago mengenai interaksi simbolik. Mead memainkan suatu peran yang penting dalam pembangunan perspektif dari mazhab Chicago yang difokuskan pada pendekatan teori sosial yang menekankan pentingnya komunikasi bagi kehidupan dan interaksi sosial.

Kedua mazhab tersebut berbeda terutama kepada metodologinya. Mead dan mahasiswanya Herbert Blumer menyatakan bahwa studi mengenai manusia tidak dapat dilaksanakan dengan menggunakan metode yang sama seperti yang digunakan mempelajari hal lainnya. Mereka mendu kung menggunakan studi kasus dan sejarah serta wawancara tidak tersetruktur. Mazhab lowa tidak mengadopsi pendekatan kuanti tatif untuk studinya. Kuhn yakin bahwa konsepsi interaksi simbolik tidak dapat dioperasionalisasi, dikuantifikasi, dan diuji. Pada titik ini, Kuhn mengembangkan sebuah teknik yang dinamakan kuesioner dua puluh pertanyaan mengenai sikap diri. Banyak koleganya yang kecewa dengan teknik penelitian Kuhn ini, salah satunya Couch. Couch mengembangakan penelitian interaksi perilaku melalui pembicaraan dan rekaman video ketimbang hanya mengem bangkan dua puluh pertanyaan mengenai sikap diri (West dan Turner, 2007).

Sebenarnya tak mudah menggo longkan pemikiran ini ke dalam teori dalam artian umum karena seperti dikatakan Paul Rock, pemikiran ini sengaja dibangun secara "samar" dan merupakan resistensi terhadap sistematisasi (1979:18-19).Ada beberapa perbedaan signifikan daiam interaksionisme simbolik, sebagian akan dibahas sambil berjalan.
Beberapa tokoh interaksionisme simbolik (Blumler, 1969a; Manis dan Meltzer, 1978; Rose, 1962; Snow, 2001 dalam Ritzer 2011) telah mencoba menghitung jumlah prinsip dasar teori ini, yang meliputi:

- Tak seperti binatang, manusia dibekali kemampuan untuk berpikir.

- Kemampuan berpikir dibentuk oleh interaksi sosial.

- Dalam interaksi sosial manusia mempelajari arti dan simbol yang memungkinkan mereka menggunakan kemampuan berpikir mereka yang khusus itu.

- Makna dan simbol memungkinkan manusia melanjutkan tindakan khusus dan berinteraksi.

- Manusia mampu mengubah arti dan simbol yang mereka gunakan dalam tindakan dan interaksi berdasarkan penafsiran mereka terhadap situasi.

- Manusia mampu membuat kebijakan modifikasi dan perubahan nya sebagian karena kemampuan mereka berinteraksi dengan diri mereka sendiri, yang memungkin kan mereka menguji serangkaian peluang tindakan, menilai keuntu ngan dan kerugian relatif mereka, dan kemudian memilih satu di antara seraigkaian peluang tindakan itu.

- Pola tindakan dan interaksi yang saling berkaitan akan membentuk kelompok dan masyarakat.

Interaksi simbolik didasarkan pada ideide mengenai diri dan hubungannya dengan masyarakat. Karena ide ini dapat diinterpretasikan secara luas, akan dijelas kan secara detail tema-tema teori ini, dan dalam prosesnya, dijelaskan pula kerangka asumsi teori ini. Ralph LaRossa dan Donald C Reitzes (1993) telah memperlajari teori interaksi simbolik yang berhubungan dengan kajian keluarga (West dan Turner, 2008).

Mereka mengatakan bahwa tujuh asumsi mendasari interaksi simbolik dan asumsi-asumsi tersebut memperlihatkan tiga tema besar (West dan Turner, 2008):

1. Pentingnya makna bagi perilaku manusia Teori interaksi simbolik bepegang bahwa individu membentuk makna melalui proses komunikasi karena tidak bersifat 
intrinsik terhadap apapun. Dibutuhkan kontruksi interpretif diantara orang-orang yang menciptakan makna. Bahkan, tujuan dari interaksi, menurut interaksi simbolik adalah unuk menciptakan makna yang sama. Hal ini penting karena tanpa makna yang sama, berkomunikasi menjadi sangat sulit, atau bahkan tidak mungkin. Menurut LaRossa dan Reitzes (1993), tema ini mendukung tiga asumsi interaksi simbolik yang diambil dari karya Herbert Blumler (1969). Asumsi - asumsinya sebagai berikut

- Manusia bertindak terhadap manusia lainnya berdasarkan makna yang diberikan orang lain pada mereka.

- Makna diciptakan dalam interaksi antarmanusia

- Makna dimodifikasi melalui proses interpretif

\section{Pentingnya konsep mengenai diri}

Tema kedua pada interaksi simbolik berfokus pada pentingnya konsep diri (self concept), atau seperangkat persepsi yan relatif stabil yang dipercaya oleh seseorang mengenai dirinya sendiri. Ketika seseorang menannyakan, "siapakah saya?" jawabanya berhubungan dengan konsep diri. Karakte ristik yang diakui oleh seseorang terkait ciri fisiknya, talenta, peranan, nilai, keadaan emosi, keterampilan, intelektulitas dan keterbatasan sosial yang membentuk konsep dirinya. Pernyataan ini merupakan hal yang penting untuk interaksi simbolik. Interaksi simbolik sangat tertarik dengan cara orang membangun konspe diri. Interaksi simbolik menggambarkan individu dengan diri yang aktif, didasarkan pada interaksi sesoal dengan orang lain. Menurut Rietzes dan LaRossa (1993) tema ini memiliki dua asumsi tambahan.

- Individu-individu mengembangkan konsep diri melalui interaksi dengan orang lain

- Konsep diri memberikan motif yang penting bagi perilaku

3. Hubungan antara individu dengan masyarakat

Tema yang terakhir berkaitan dengan hubungan antara kebebasan individu dan batasan sosial. Mead dan Blumer mengambil posisi di tengah untuk perta nyaan ini. Mereka mencoba untuk menjelaskan baik mengenai keteraturan dan perubahan dalam proses sosial. Asumsiasumsi yang berkaitan dengan tema ini adalah :

- Orang dan kelompok dipengaruhi oleh proses budaya dan sosial

- Struktur sosial dihasilkan melalui interaksi social

\subsection{Kerangka Berpikir}

Denelitian ini ingin melihat bagaimana aktor (subyek penelitian-masyarakat kota Pariaman, memaknai Tabuik sebagai tradisi yang sedang tumbuh kembang di dekatnya. Penelitian ini dimulai dengan asumsi bahwa ; seorang (bila ia inginkan), bisa memaknai Tabuik sesuai dengan keinginannya, dengan siapa dan pada lingkungan mana dia berinteraksi, cepat atau lambat akan mempengaruhi pandangan atau pemikirannya. Pandangan atau pemikirannya itulah pada akhirnya yang akan menentukan makna Tabuik bagi dirinya. Berdasarkan asumsi tersebut dapat dijelaskan bahwa keputusan seseorang untuk memaknai Tabuik tidak muncul begitu saja, namun lahir dari suatu proses konstruksi yang sadar; dan ia bertindak menurut hasil rumusan situasi yang dibuatnya. Secara instrinsik, suatu obyek tidak memiliki makna apa-apa. Manusialah yang memberikan makna tertentu pada obyek yang dijumpainya. Memberikan makna berarti memahamai apa arti sebuah simbol, kemudian bertindak atas dasar pemahaman itu.

Pendekatan atau teori interaksi simbolik digunakan untuk mengkonstruksi dan menganalisis proses pemaknaan Tabuik oleh masayarakat. Kelebihan dari pendekatan interaksionisme simbolik ini adalah karena adanya pengakuan bahwa "manusia adalah mahkluk yang berpikir." Artinya, perspektif ini mengakui bahwa tidaklah mudah bagi siapapun merubah sikap dan perilakunya, hanya karena adanya satu atau dua stimulus, apalagi jika sikap dan perilaku yang dimaksud telah menjadi kebiasaan atau budaya baginya. Keberadaan significant others maupun situasi yang mendukung tidak serta merta merubah perilaku seseorang, tetapi kedua hal tersebut akan diterjemahkan lebih dulu melalui proses berpikir. Sebelum mengambil keputusan, aktor berdialog (berinteraksi) dengan diri pribadi (self-interaction). Secara 
singkat kerangka pemikiran dari penelitian ini sebagaimana dijelaskan di atas disajikan dalam bentuk skema berikut ini :

Gambar 1. Kerangka Berpikir

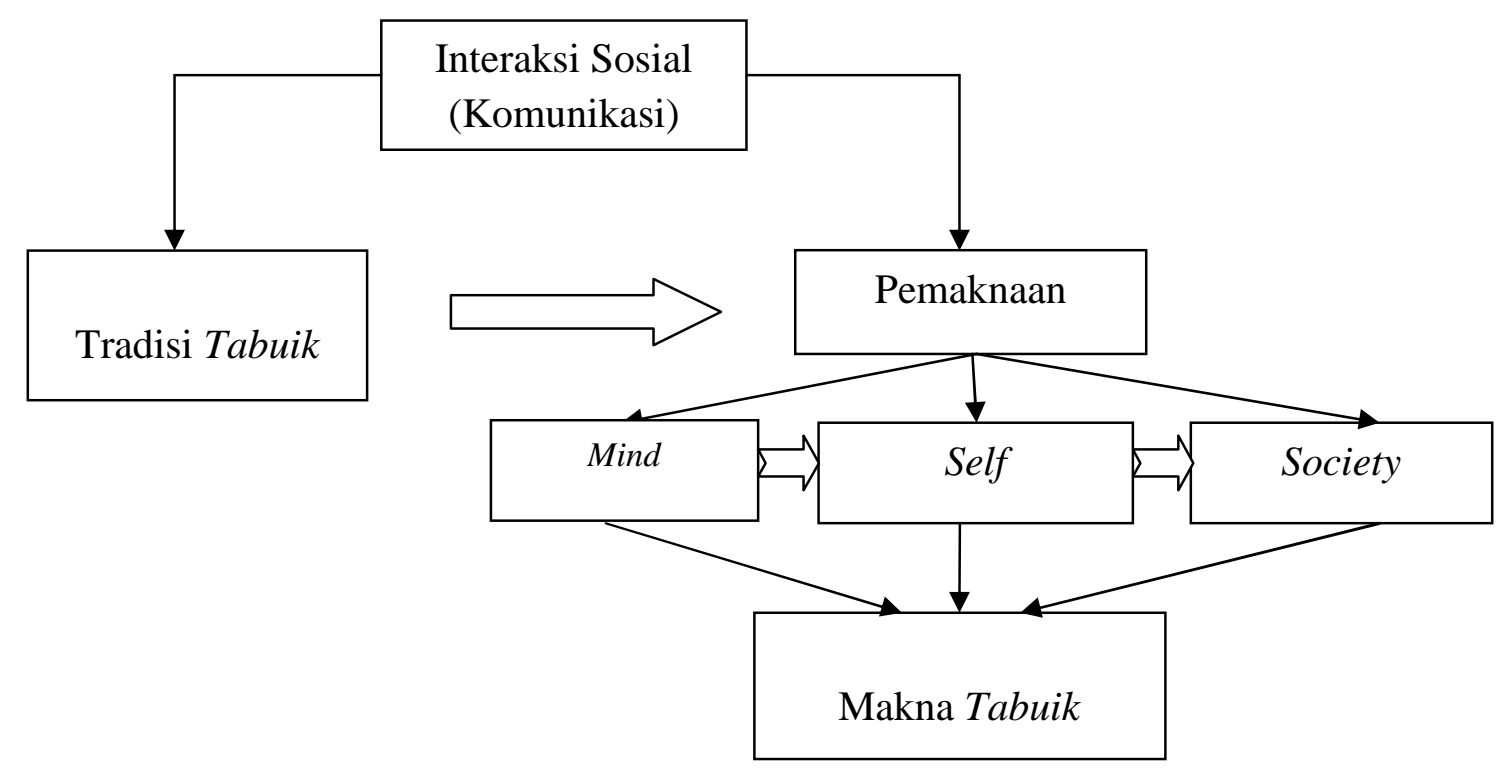

\section{METODE PENELITIAN}

P enelitian dilakukan di Kota Pariaman. Lokasi ini dipilih karena merupakan lokasi pelaksanaan ritual Tabuik. Penelitian ini menggunakan desain penel itian studi kasus observasi. Melalui teknik observasi pada studi kasus bisa diperoleh keterangan atau informasi empiris yang detail dan akurat dari unit analisis penelitian (Bungin, 2010). Untuk mengetahui berbagai masalah dalam melakukan pelaksanaan Tabuik diperlukan data primer yang diperoleh berdasarkan wawancara menda lam (in depth interview). Pengolahan data dilakukan dengan teknik Miles dan Habermas. Data sekunder berupa referensireferensi yang dibutuhkan untuk penelitian ini berupa dokumen-dokumen pelaksanaan ritual Tabuik.

Sumber data primer dalam penelitian adalah data yang diperoleh dari informan. Peneliti melakukan wawancara mendalam untuk memperoleh informasi. Informan penelitian adalah masyarakat yang tahu dan terlibat dengan ritual Tabuik. Peneliti menggunakan 5 orang informan penelitian, yakni masyarakat yang menyaksikan secara langsung proses pem buatan Tabuik dan pelepasan Tabuik ke laut. Selain wawancara peneliti juga melakukan observasi dengan teknik observasi non partisipan. Peneliti melakukan observasi dan wawancara sejak pertenga han September hingga akhir Oktober 2016.

Selanjutnya untuk menguji apakah data yang telah dikumpulkan adalah benar (valid) maka dilakukan triangulasi. Triangulasi adalah teknik pemeriksaan keabsahan data yang memanfaatkan sesuatu yang lain (Moleong 2007). Triangulasi dilakukan melalui wawancara mendalam dengan tokoh-tokoh masyarakat yang dianggap memahami Tabuik. Pada penelitian ini yang menjadi triangulator adalah Yusral selaku Niniak Mamak, Epi selaku urang Tabuik dan Zulbakri alias Mak Etek selaku Tuo Tabuik.

Data yang diperoleh melalui kajian ini merupakan data kualitatif dan dianalisis secara kualitatif. Analisis data kualitatif adalah upaya yang berlanjut, berulang dan terus menerus. Analisis data dalam penelitian ini berlangsung bersamaan de ngan proses pengumpulan data dimulai dari sebelum data benar-benar terkumpul sampai dengan penulisan laporan peneliti an. Menurut Miles dan Huberman (2007), tahap-tahap analisis data meliputi: pertama reduksi data, intinya mengurangi atau membuang data yang tidak penting (tidak relevan) yang ada pada catatan harian dan transkrip wawancara, sehingga data terpilih 
dapat diproses ke langkah selanjutnya. Kedua penyajian data yaitu menyajikan data dalam berbagai bentuk seperti cuplikan percakapan, catatan wawancara, dan fotofoto dengan tujuan untuk memudahkan dalam memahami apa yang terjadi, merencanakan kerja selanjutnya berdasar kan apa yang dipahami. Ketiga, Pengambilan keputusan dan verifikasi yaitu menyimpulkan dan mengecek ulang datadata yang telah direduksi dan disajikan. Ketiga tahapan tersebut berlangsung secara simultan.

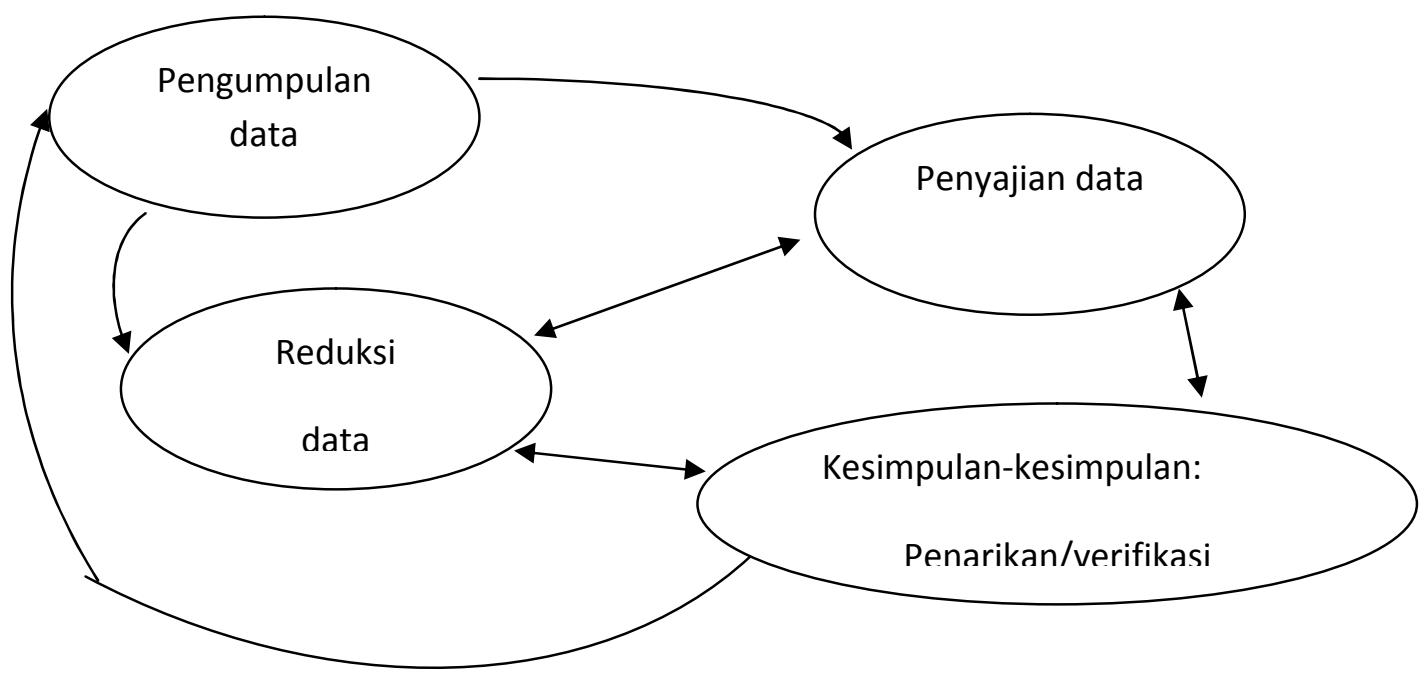

Gambar2. Proses Analisis Data Penelitian

\section{HASIL DAN PEMBAHASAN}

\subsection{Profil Kota Pariaman}

$\mathrm{K}$ ota Pariaman merupakan salah satu dari 19 Kabupaten/Kota yang ada di Provinsi Sumatera Barat. Kota Pariaman resmi dinobatkan sebagai Kota Otonom berdasarkan UU Nomor 12 tahun 2002. Kota Pariaman posisinya berada pada $0^{\circ} 33^{\prime} 00^{\prime \prime}$ s.d. $0^{\circ} 40^{\prime} 43^{\prime \prime}$ Lintang Selatan dan $100^{\circ} 04^{\prime} 46^{\prime \prime}$ sampai dengan $100^{\circ} 10^{\prime} 55^{\prime \prime}$ Bujur Timur. Luas wilayah Kota Pariaman tercatat $73,36 \mathrm{~km} 2$ atau hanya 0,17 persen dari luas wilayah Provinsi Sumatera Barat yang mencapai 42.297,30 km2. Jarak Kota Pariaman lebih kurang 56 kilometer dari Kota Padang dan $25 \mathrm{~km}$ dari Bandara Internasional Minangkabau. Seluruh wilayah Kota Pariaman berbatasan dengan Kabupaten Padang Pariaman dan terbagi kedalam empat kecamatan yakni: Kecamatan Pariaman Selatan, Pariaman Tengah, Pariaman Utara dan Pariaman Timur.

Seperti pada umumnya daerah lain yang berada di bagian Pantai Barat pulau Sumatera, Kota Pariaman memiliki jenis bebatuan resen dan tuna vulkan. Kota
Pariaman dilalui oleh tiga buah sungai yaitu Batang Manggung yang melalui Kecamatan Pariaman Utara, Batang Piaman, yang melewati Kecamatan Pariaman Tengah serta Batang Mangau yang melalui Kec. Pariaman Selatan. Topografi wilayah, geomorfologi dan morfologi wilayah secara bersama-sama telah membentuk pola aliran sungai.

Penduduk memiliki peran besar dalam menjalankan roda perekonomian suatu wilayah. Akan tetapi persoalan kependudukan apabila tidak diatasi dengan baik akan menjadi penghalang dalam proses pembangunan itu sendiri. Oleh karena itu, persoalan jumlah, komposisi dan laju pertumbuhan penduduk perlu menjadi perhatian Pemerintah Kota Pariaman. Pada tahun 2015 jumlah penduduk Kota Pariaman telah mencapai 84.709 jiwa. Angka ini mengalami peningkatan 1.099 jiwa diabanding tahun 2014.

Faktor lain yang perlu juga menjadi perhatian Pemerintah Kota Pariaman adalah kepadatan penduduk. Kepadatan penduduk adalah perbandingan jumlah penduduk dengan luas wilayah, Dengan artian 
banyaknya jumlah penduduk di suatu wilayah untuk setiap kilometer persegi. Semakin tinggi tingkat kepadatan penduduk maka semakin kompleks permasalahan sosial yang akan dihadapi oleh suatu daerah begitu juga sebaliknya. Dari empat kecamatan di Kota Pariaman, Kecamatan Pariaman Tengah merupakan kecamatan terpadat dengan kepadatan penduduk sebanyak 1.932 jiwa/km2. Sedangkan yang memiliki kepadatan penduduk terendah adalah Kecamatan Pariaman Timur dengan jumlah 883 jiwa/km2.

Letak Kota Pariaman yang berada di pantai Samudera Hindia memiliki potensi wisata bahari yang menjanjikan. Sektor pariwisata ditargetkan dapat menjadi salah satu sektor yang memiliki peranan penting dalam perekonomian Kota Pariaman. Objek wisata di Kota Pariaman merupakan perpaduan wisata alam, budaya, dan sejarah. Kota Pariaman memiliki 23 objek wisata, yang terbanyak berupa objek wisata alam termasuk pantai. Pada tahun 2015 terjadi penambahan satu objek wisata di Kota Pariaman yaitu dengan dibukanya objek wisata sejarah benteng Jepang santok di Pariaman Timur. Potensi wisata pantai Kota Pariaman terbentang luas dan unik, dengan butiran pasir putih yang bercampur dengan batu apung dan karang-karang kecil yang menghiasi indahnya bibir pantai. Kota Pariaman juga memiliki pulau-pulau kecil yang berada di sekitar Pantai dan tempattempat kuliner terkenal dengan nasi Sek (dulu akronim dari Seribu Kenyang, sekarang menjadi Sepuluh Ribu kenyang).

Salah satu tradisi yang menjadi wisata budaya di Kota Pariaman adalah wisata Tabuik. Wisata Tabuik diperangingati pada bulan muharram setiap tahunnya. Wisata Tabuik menjadi event andalan yang penyelengaaraannya selalu dinantikan setiap tahunya.

4.2. Makna Tabuik Oleh Masyarakat Pariaman dan Proses Desakralisasi Tabuik Piaman

$T$ abuik berasal dari bahas arab yang berarti keranda atau peti mati. Tabuik adalah tradisi budaya yang dilakukan oleh masyarakat Pariaman untuk mempe ringati meninggalnya cucu Nabi Muhammad SAW yaitu Hasan dan Husein di Padang Karbala. Kata Tabuik atau Tabot atau Tabut merujuk pada upaya yang dilakukan oleh kaum Syiah dulu untuk mengumpulkan potongan tubuh kedua cucu Rasulullah dan memakamkannya setelah terbunuh di Padang Karbala. Prosesi Festival Tabuik di Pariaman dilakukan setiap tahun mengikuti kalender Hijriah setiap bulan Muharram mulai tanggal 1 sampai puncaknya pada tanggal 10. Pada Tanggal 10 Muharram Tabuik diarak keliling Kota dan dibuang ke laut.

Tradisi Tabuik diawali dengan maambiak tanah dan biasanya pembuatan berlangsung selama hampir 2 minggu (idealnya 1-10 Muharram, namun biasanya puncak perayaan disesuaikan dan biasanya ditetapkan hari minggu setelah 10 muharram). Pembuatan Tabuik dilakukan di Rumah Tabuik. Tabuik yang dibuat berjumlah dua buah atau satu pasang dibuat masing-masing di Rumah Tabuik Pasa (Tabuik Pasa) dan di Rumah Tabuik Subarang (Tabuk Subarang).

Tabuik sendiri berbentuk seperti kuda, memiliki sayap namun berkepala manusia. Konon bentuk ini adalah perwujudan Buraq yang dipercaya membawa tubuh Husein ke langit. Tabuik memiliki tinggi 12 meter dan pada saat pembuatannya dibuat dalam dua bagian. Bagian atas menyimbolkan beranda berbentuk menara yang dihias sedemikian rupa, sedangkan bagian bawah berbentuk Buraq.

Pada Festival Tabuik peristiwa Padang Karbala seperti direka ulang. Hal tersebut dimulai dari prosesi maambiak tanah, maatam, maarak jari-jari, maarak saroban dan rangkaian ritual lainnya. Setiap prosesi dan ritual memiliki makna tersendiri. Pada puncak perayaan Festival Tabuik prosesi yang dilakukan dinamakan "Hoyak Tabuik". Pada prosesi ini Tabuik diarak dan akhirnya dibuang ke laut. Setelah itu barulah keseluruhan Festival Tabuik berakhir.

Festival Tabuik sendiri memiliki sejarah panjang di Pariaman. Mengenai masuknya Tabuik sendiri ada beberapa versi. Selain itu keterkaitan Tabuik dengan Syiah sampai saat ini juga menjadi kontroversi di tengah masyarakat. Dulunya Tabuik merupakan acara rakyat masyarakat Pariaman. Baru kemudian pada tahun 1970an, Tabuik diangkat menjadi Festival Budaya oleh Pemerintah Kabupaten Padang Pariaman saat itu agar bisa mendatangkan wisatawan ke Pariaman. Saat ini Tabuik di 
Pariaman telah menjadi Festival Budaya yang banyak menarik wisatawan, tidak hanya lokal tapi juga mancanegara.

Upacara Tabuik mewakili cerminan sikap dan pola hidup masyarakat Pariaman. Bahkan Tabuik dijadikan sebuah tradisi bagi masyarakat yang tidak dapat dipisahkan dari kehidupan warga Pariaman. Kemudian, Tabuik dilaksanakan oleh Anak Nagari dalam bentuk Tabuik Budaya (Dwiyanti, 2015).

Eksistensi Tabuik di tengah-tengah masyarakat telah terkontaminasi dan terganggu oleh desakan daerah, pariwisata, dan otoriter pemerintahan. Pesta budya Tabuik adalah salah satu target utama pariwisata Indonesia yang ditawarkan Propinsi Sumatera Barat. Seiring perkem bangan zaman, upacara Tabuik ini pelaksanaannya tidak lepas dari event pariwisata yang dijadikan sebuah atraksi kebudayaan.

Upacara Tabuik ini merupakan suatu simbol bentuk ekspresi rasa duka mendalam dan rasa hormat umat Islam di Pariaman terhadap cucu Nabi Muhammad SAW yang tewas secara tidak wajar pada peperangan di Pada Karbala (Dwiyanti, 2015). Pada pelaksanaanya Tabuik sendiri terbagi menjadi dua yakni Tabuik Pasa dan Tabuik Subarang. Upacara Tabuik ini terdiri atas 3 bagian. diawali dengan pra Tabuik, proses pembuatan Tabuik, dan diakhiri dengan pembuangan Tabuik ka Lauik (pembuangan Tabuik ke laut). Lebih lengkapnya sebagai berikut:

\section{Pra Tabuik}

Pra Tabuik adalah kegiatan pembentukan panitia dan musyawarah serta persiapan-persiapan dalam melakukan event ini. Sedangkan proses pembuatan Tabuik adalah kegiatan membuat Tabuik itu sendiri. Upacara Tabuik ini berlangsung kurang lebih selama 15 hari, dimulai dari tanggal 1 Muharam hingga puncak acaranya pada hari minggu yang mendekati 10 Muharam. Pada tahun ini berlangsung dari tanggal 1 Oktober hingga 16 oktober 2016. Acara diawali dipadukan dengan event lainnya seperti Tabligh Akbar di tanggal 1 Oktober 2016 dan Seminar Tabuik sehari sebelum pelepasan Tabuik yakni tangal 15 Oktober 2016. Seminar Tabuik menda tangkan para akademisi yang melakukan kajian terhadap Tabuik seperti Buya Duski
Samad melakukan kajian agama, Penulis buku Sejarah Tabuik, Asril Muchtar dari sisi budaya dan Khanizar Chan seorang sejarawan untuk memberikan pemahaman tentang Tabuik kepada Masyarakat. Pelaksanan Tabligh Akbar dan Seminar Tabuik ini juga dimaksudkan untuk menepis isu Syiah yang berkembang di tengah masayarakat. Tabuik sendiri memiliki nilainilai sakral yang pada dasarnya jauh dari Syiah. Pelaksanaan event ini saat ini bukanlah merupakan event keagamaan tetapi menjadi event kepariwisataan dan salah satu media untuk mengembangkan tradisi yang telah lama tumbuh dan berkembang di tengah masyarakat Pariaman.

Kegiatan pra Tabuik berlangsung jauh sebelum tanggal 1 muharram. Kegiatannya seperti menngumpulkan pe mangku adat dan pelaku tabuik, niniak mamak, tuo tabuik, anak tabuik, anak nagari dan pihak-pihak lainnya yang memiliki kapasitas dan kompetensi dalam penyelenggaraan event Tabuik. Pihak-pihak tersebut melakukan musyawarah terkait tahapan prosesi, masalah teknis, pengumpulan dana, hingga pembagian kerja. Hal ini diperlukan untuk menciptakan situasi dan suasana yang kondusif dalam penyelenggaranan tradisi Tabuik. Pelak sanaan Tabuik sudah diserahkan ke Peme rintah Kota Pariaman dengan melibatkan pemangku adat dan pelaku Tabuik. Tabuik menjadi salah satu agenda pariwisata di Kota Pariaman. Penyelenggaraan Tabuik disisipi dengan rangkaian acara lainnya, seperti lomba pagelaran seni, lomba tari Indang kreasi, lomban nyanyi dangdut/ melayu.

\section{Pembuatan Tabuik}

Pada pembuatan Tabuik yang dimulai tanggal 1 Muharram (1 Oktober 2016) diawali dengan maambiak tanah (mengambil tanah), manabang batang pisang (menebang batang pisang), maatam (ekspresi kesedihan), maarak jari-jari (mengarak jari-jari), maarak sorban (mengarak sorban), Tabuik naik pangkek (Tabuik naik pangkat). Rincian pelaksana annya sebagai berikut :

a. Maambiak Tanah

Maambiak Tanah merupakan prosesi ritual pengambilan segumpal tanah ke sungai yang dilakukan pada tanggal 1 
Muharram. Prosesi ini dilakukan bersamaan oleh Tabuik Pasa dan Tabuik Subarang. Pengambilan dilakukan pada sungai yang berbeda. Tabuik Pasa mengambil tanah di sungai kecil di Galombang, sedangkan Tabuik Subarang mengambil tanah di sungai batang piaman di daerah Pauh. Sebelum melakukan prosesi ini kedua kelompok Tabuik terlebih dahulu membuat daraga. Daraga adalah sebuah tempat yang dilingkari dengan pagar bambu berbentuk segi empat yang memiliki luas kurang lebih 5 meter, dikelilingi kain putih (Gambar 3). Daraga ini diibaratkan seperti makam. Prosesi maambiak tanah diiringi dengan gandang tansa (Gambar 4 kiri). Iring-iringan berjalan kaki dari daraga ke lokasi pengambilan tanah yang dimulai dengan do'a bersama. Pengambilan tanah dilakukan oleh Tuo Tabuik dengan menggunakan kain putih, waktu pengambilan adalah sebelum shalat maghrib (Gambar 4 kanan).

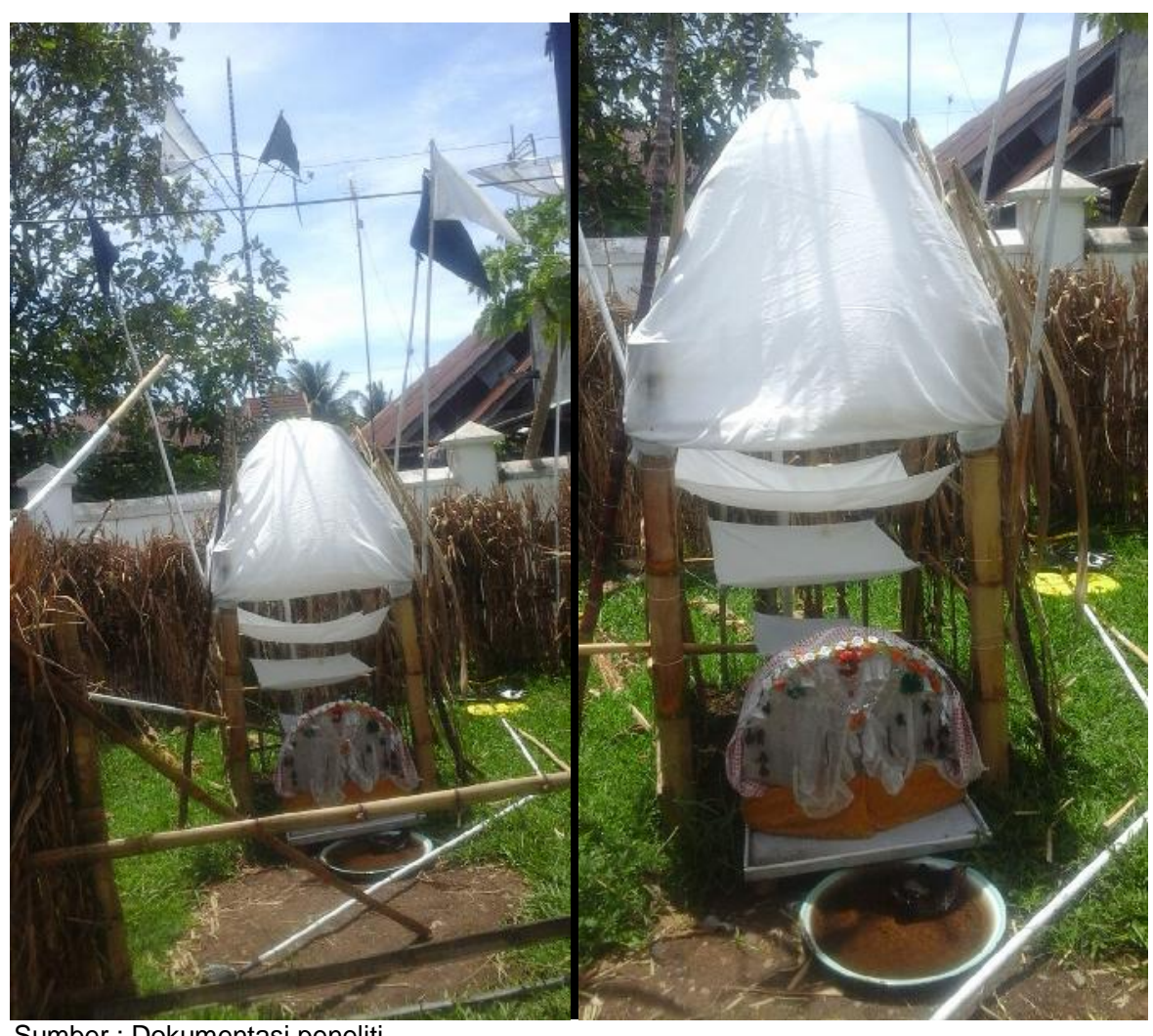

Sumber : Dokumentasi peneliti

Gambar 3. Daraga 


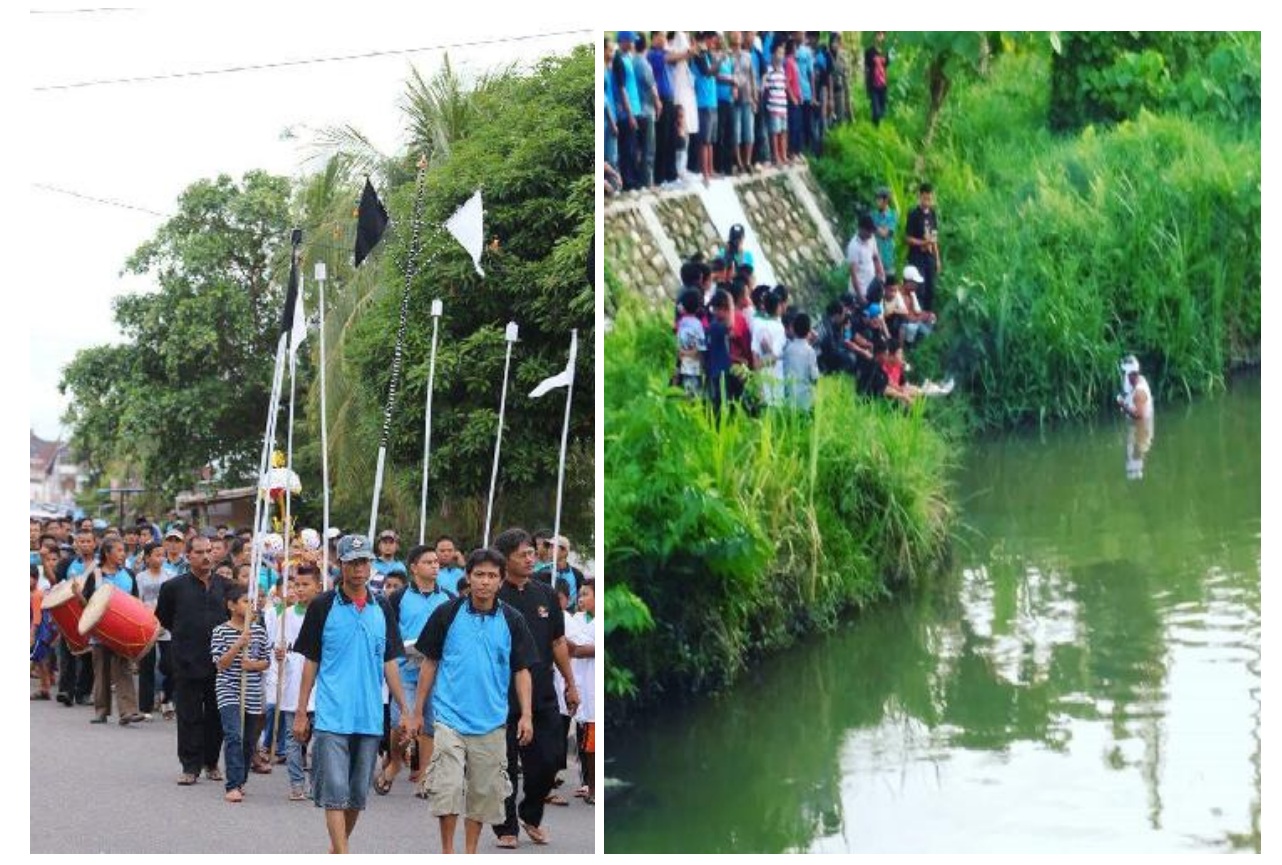

Gambar 4. Iring-iringan Gandang Tansa (kiri) dan Prosesi Maambiak Tanah ( kanan, sumber : instagram @dedecokes)

Tanah yang diambil kemudian diletak kan di belanga dan ditutup kain putih, kemudian diletakkan dalam daraga. Pengambilan tanah menggambarkan pengambilan mayat Husein di sungai Eufrat di Karbala. Pada kenyataannya tidak semua masyarakat Pariaman yang mengikuti ritual tabuik memahami ini. Pada umumnya tidak memiliki pemaknaan terhadap prosesi ini, yang diketahui adalah bahwa prosesi ini merupakan salah satu tahapan dalam batabuik. Pada tahun ini pelaksanaan maambiak tanah dilakukan pada tanggal 1 Muharram $1437 \mathrm{H}$.

b. Manabang Batang Pisang

Manabang batang pisang merupakan prosesi memancung beberapa batang pisang (Gambar 5) yang kemudian batang pisang tersebut diletakkan dalam daraga. Pelaksanaan prosesi ini dilakukan bersamaan oleh kelompok Tabuik Pasa dan Tabuik Subarang. Biasanya prosesi ini diakhiri perseteruan (bacakakberkelahi) antar kedua kelompok Tabuik, perseteruan terjadi ketika kedua kelompok ini berselisih jalan dan masing-masing masih diiringi gandang tansa. Lokasi penebangan batang pisang ini juga berbeda antar kedua kelompok Tabuik, pelaksanaan dilakukan sebelum shalat maghrib. Batang pisang harus putus dalam satu kali tebasan. Menurut Muchtar (2016), penebangan batang pisang diibaratkan presentasi simbolik tentara Yazid yang merampas harta keluarga Husain. Pada pelaksanaannya perseteruan antar kedua kelompok Tabuik inilah yang dinanti oleh anak tabuik. Menurut informan ini merupakan representasi simbolik perang Karbala. Perselisihan tersebut kemudian akan berakhir disana, tidak berlanjut ke harihari berikutnya karena hanya merupakan simbol. Prosesi ini dilakukan pada tanggal 5 Muharram. 


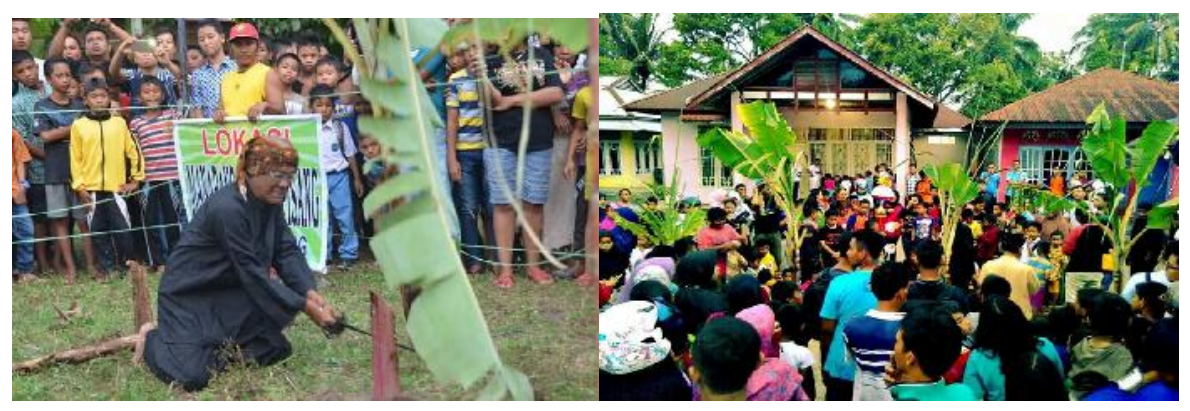

\section{Gambar 5. Manabang Batang Pisang}

c. Maatam

Maatam adalah prosesi yang menggam barkan kesedihan atas penderitaan yang dialami Husain pada saat perang Karbala. Prosesi dilakukan pada tanggal 7 Muharram setelah shalat dzuhur oleh keturunan Rumah Tabuik yang perempuan. Berdasarkan penutu ran informan, maatam ini memiliki makna meratapi kepergian orang yang telah meninggal. Pada prosesi maatam, keturunan Rumah Tabuik yang melakukan prosesi ini memiliki pantangan selama prosesi Tabuik, apabila dilanggar maka akan ada kejadian-kejadian yang tidak diharap kan terjadi pada Rumah Tabuik dan keturunannya.

\section{d. Maarak Jari-jari}

Maarak jari-jari dilakukan pada hari yang saman dengan maatam yakni tanggal 7 Muharram sebagai kelanjutan acara maatam. Pada tahun 2016 ini maarak jari-jari diselenggarakan sete lah sholat maghrib. Maatam dapat diartikan sebagai kegiatan arak-rakan yang dilakukan oleh kelompok Tabuik Prosesi dilakukan oleh kedua kelompok Tabuik Pasa dan Tabuik Subarang dengan mengambil lokasi di daerah sendiri dan daerah kelompok Tabuik lainnya. Kegiatan arak-arakan dilaku kan dengan membawa panja, yakni sebuah kubah yang terbuat dari kertas kaca dan bambu serta diberikan lilin, kertas tersebut berisikan gambar tangan dengan jari-jari yang putus. Penuturan informan mengungkapkan maarak jari-jari ini melambangkan jarijari Husain yang dipotong oleh musuh.
Kegiatan maarak jari-jari diiringi dengan gandang tansa.

e. Maarak Saroban

Ritual Maarak saroban atau mengarak sorban (turban) berlangsung tanggal 9 Muharram. Ritual dilaksanakan pada malam hari tepatnya setelah shalat maghrib. Kegiatan arak-arakan juga diiringi oleh musik gandang tansa, tidak jarang pada saat arak-arakan terjadi perselisihan antara kelopok Tabuik Pasa dangan Tabuik Subarang. Ritual ini memiliki makna mendorong semangat membela kebenaran, pesan yang disampaikan adalah agar menggunakan logika rasional dalam bertindak.

f. Tabuik Naiak Pangkek

Tabuik naiak pangkek adalah prosesi penggabungan pangkek bawah (tabuik bagian bawah) dengan pangkek ateh (tabuik bagian ateh). Idealnya sesuai dengan nilai-nilai sakral prosesi tabuik itu sendiri ritual ini berlangsung pada tanggal 10 Muhharam, namun pada penelitian ini Tabuik Naiak Pangkek berlangsung pada tanggal 16 Muhar ram. Berdasarkan tersebut, dapat dikatakan telah terjadi desakralisasi nilai tabuik. Hal ini dikarenakan tanggal 16 Muharram bertepatan dengan hari Ming gu sehingga diprediksi akan banyak wisatawan yang datang dibanding jika dilaksanakan pada hari kerja/sekolah (Senin-Sabtu). Tujuannya adalah untuk meningkatkan pendapatan daerah dengan belanja wisatawan pada saat acara tabuik berlangsung. Setelah tabuik naiak pangkek maka selanjutnya adalah mengarak tabuik-tabuik tersebut. Tabuik tersebut ada dua kelompok, 
yakni tabuik berkepala wanita dan tabuik berkepala pria.

\section{Pembuangan Tabuik ke Laut}

Bagian terakhir dari prosesi adat ini adalah pembuangan tabuik ke laut. Sebelum ritual ini berlangsung,sebelumnya dilakukan pengarakan Tabuik tersebut yang diarak keliling Nagari atau keliling kampong oleh Tabuik Pasa dan Tabuik Subarang. Arakarakan ini juga dikenal dengan istilah hoyak tabuik. Hoyak Tabuik merupakan sajian atraksi dari tabuik itu sendiri, seperi merebahkan, memutar, menggoyahkan, melarikan. Hoyak tabuik diiingi dengan gandang tansa dengan menyebut kata-kata hoyak,hosen, dan sosoh (Gambar 6). Seruan tersebut dilakukan berulang-ulang sambil melakukan atraksi hoyak tabuik. Arak-akan nini akan berhenti di pantai gondoriah karena disanalah tabuik kan dibuang.
Tabuik dibuang ke laut sesaat sebelum terbenamnya matahari. Saat Tabuik Pasa dan Tabuik Subarang dibuang ke laut, terjadi perebutan dari tabuik itu sendirin oleh warga sekitar. Warga berebut mengambil potong-potongan tabuik untuk dibawa pulang. Potongan tabuik tersebut dipercaya bisa dijadikan pelaris dalam berdagang. Disini telah terjadi pergesearan makna, makna yang sebnarnya adalah membuang permasalahan, tetapi yang dimaknai oleh masyarakat adalah terdapat undur syirik, yakni mempercayai potongan tabuik sebgai pelaris jualan. Observasi peneliti mengungkapkan bahwa yang mengambil potongan-potongan tabuik tersebut tidak hanya laki-laki dan anak muda, tetapi juga anak-anak dan ibu-ibu paruh baya. Bahkan saat penelitian ini, terjadi hujan deras, namun tak menyuruti langkah beberapa warga untuk mendapatk potongan-potingan kerangka tabuik.

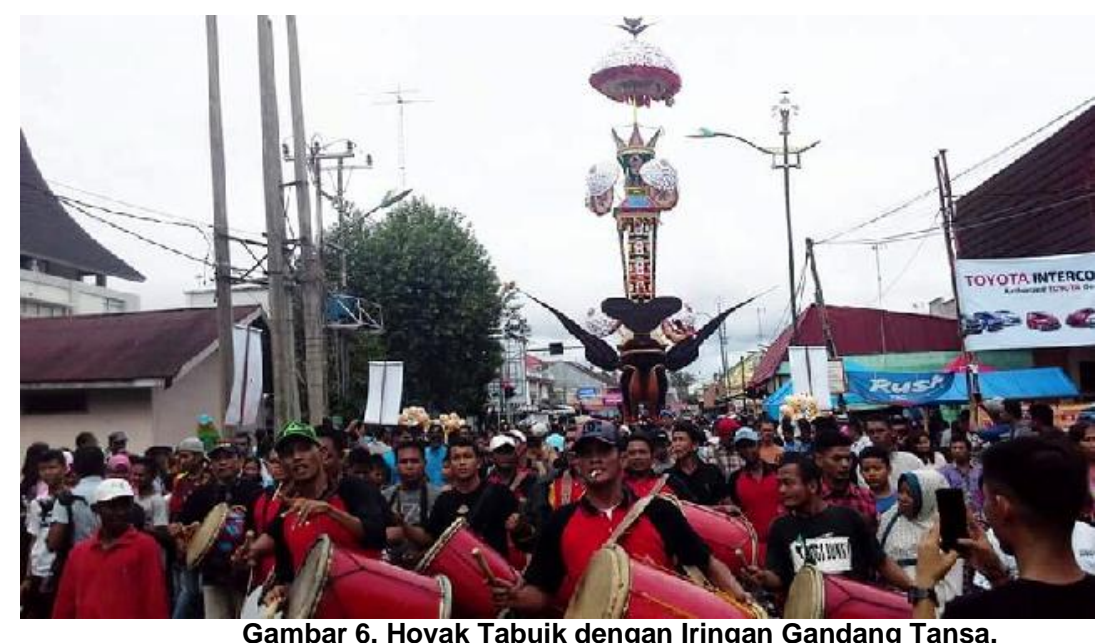

Masyarakat Pariaman secara umum memahami bahwa mereka memiliki tradisi ritual batabuik yang telah dilakukan sejak kurun waktu yang lama. Akan tetapi, sangat sedikit sekali yang bisa memahami dalam pelaksanaan perayaan atau pesta Tabuik itu sendiri ada perbedaan yang mendasar (Muchtar, 2016). Tabuik sejatinya adalah identitas budaya, bukan peringatan keagaaman. Namun akhir-akhir ini pelak sanaannya oleh Pemerintah Kota bersinergi dengan masyarakat Tabuik, tabuik telah dijadikan event pariwisata yang pelaksa naannya diagendakan dalam kegiatan tahunan. Disini terdapat beberapa pergeseran dalam pelaksanaan acara tabuik. Sejalan dengan pendapat Muchtar (2016), bahwa tabuik bertahan dan berkembang melalui ideologi masyrkatnya.

Catatan peneliti menyebutnya setidaknya terdapat 3 makna dalam penyelenggaraan tabuik ini, antara lain :

1. Makna yang terbentuk oleh masyara kat.

Makna yang terbentuk oleh masyarakat antara lain, bahwa penyelengaraan tabuik adalah event tahunan, event pariwisata, dimana disana menjadi 
ajang kumpul dan silaturrahmi oleh warg Pariaman. Salah satu informan menyebutkan sebagai "ajang baramirami” (ajang beramai-ramai). Baginya ini adalah momentum untuk dia dan anak-anaknya melakukan wisata ke pantai gondoriah, melihat pelepasan tabuik dan mengajarkan pada anak mereka bahwa ini adalah tradisi Pariaman. Hal ini mengungkapkan bahwa penyelenggaranan tabuik dapat menjadi sarana hiburan bagi masyarakat setempat. Observasi peneliti juga menemukan sebagian masyarakat yang mengambil potingan kerangka tabuik untuk dijadikan sebgai peris jualan oleh pedagang. Kerangka tersebut setelah didaptkan kemudian disimpan di tempat yang aman.

2. Makna yang terbentuk oleh pemerintah

Berdasarkan hasil penelitian ini, hasil observasi peneliti mengungkapkan bahwa oleh pemertintah Tabuik dijadi kan sebagai event pariwisata. Dimana penyelenggaraannya sudah dimasuk kan ke dalam agenda tahunan pemerintah kota Pariaman. Hal ini terbukti dengan sudah mulai tergerus nya nilai-nilai sakral dalam ritual tabuik seperti penyelenggaraan tabuik dibuang ka lauik yang tidak lagi di tanggal 10 Muharam, tapi disesuaikan dengan kalender. Penentuan tanggal nya adalah berdsarkan hari libur yang dekat dengan tanggal 10 Muharram.

3. Makna yang terbentuk oleh pemangku adat danu urang tabuik.

Makna yang terbentuk adalah bahwa tabuik merupakan tradisi yang harus tetap dijaga kelestaraiannya. Tabuik merupakan sebuah tradisi yang harus dipertahankan dan dijagha meski tantangan zaman mulai menggerus nilai-nilai tabuik itu sendiri.
Makna yang terbentuk baik oleh masyarakat, pemerintah maupun urang tabuik berasal dari proses interaksi yang terjadi di masyarakat kota Pariaman. Pada konsep mind teori Interaksi Simbolik dikatakan bahwa makna adalah perilaku manusia, manusia bertindak terhadap objek berdasarkan makna yang diberikan oleh orang lain pada mereka. Pada tabuik, makna yang diberikan tercipta oleh danya tantangan zaman. Makna tersebut dimodifikasi melalui proses interpetatif. Kemudian pada level self concept, individuindividu (masyarakat) mengembangkan makna melalui interkasi dengan orang lain. Konsep diri yang memberikan motif bagi perilaku. Ketika masyarakat berbondongbondong itu mendapatkan potongan kerangka tabuik konsep diri yang mereka miliki adalah bahwa mereka percaya bahwa potongan tersebut bisa dijadikan pelaris. Hubungan antara tabuik dengan masyarakat dipengaruhi oleh proses budaya dan sosial, yang dihasilkan melalui interaksi sosial.

\section{E. KESIMPULAN}

Berdasarkan pembahasan di atas dapat disimpulkan bahwa :

1. Makna Tabuik yang terbentuk oleh masing-masing pihak. Oleh masyara kat, tabuik dijadikan sebagai ajang hiburan. Oleh pemerintah, tabuik dijadi kan sebagai agenda pariwisata, sedangkan oleh urang tabuik, tabuik masih dijadikan sebagai tradisi budaya yang patut dilestarikan.

2. Proses desakralisasi terjadi akibat adanya tantangan zaman tabuik berkembang sesuai dengan ideology nya. Pelaksanaan tabuik sudah jauh bergeser, namun masih tetap dipertahankan sebagai tradisi budaya masyarakat Pariaman.

\section{Daftar Pustaka}

Bungin, B. 2010. Analisis Data Penelitian Kualitatif. PT Raja Grafindo Perkasa.

Creswell John W. 2010. Research Design Pendekatan Kualitatif, Kuantitatif, dan Mixed. Achmad Fawaid, penerjemah. Yogyakarta (ID): Pustaka Belajar. Terjemahan dari: Research Design Qualitative, Quantitative, and Mixed Methods Approaches, Ed ke-3. 
Devito Joseph A. 2011. Komunikasi Antarmanusia. Agus Maulana, penerjemah; Lyndon saputra, Istiyono Wahyu, Yuni Prihantini, editor. Tanggerang (ID): Karisma Publising Group. Terjemahan dari: Human Communication, Ed ke-5.

Dwiyanti, Vina. 2015. Makna Simbolik Upacara Tabuik di Kota Pariaman Sumatera Barat. Jurnal FISIP Volume 2 Februari 2015

Effendy, O.U. 1989. Kamus Komunikasi. Bandung : PT.Mandar Maju.

Effendy, O.U. 2007. Ilmu, Teori dan Filsafat Komunikasi. Bandung : Citra Aditya Bakti.

Muchtar, Asril; dkk. 2016. Sejarah Tabuik. Pariaman : Dinas Kebudayaan dan Pariwisata Kota Pariaman.

Mulyana dan Jalaluddin Rakhmat. Bandung (ID): Rosdakarya.

Mulyana Deddy. 2010. IImu Komunikasi Suatu Pengantar. Bandung(ID): Rosda Karya.

Mulyana, D. 2007. Metode Penelitian Komunikasi. Bandung : PT. Remaja Rosdakarya

Moleong Lexy J. 2007. Metodelogi Penelitian Kualitatif. Bandung(ID): Remaja Rosdakarya.

Porter, Richard E dan Larry A. Samovar. 2005. Komunikasi Antarbudaya Panduan Berkomunikasi dengan Orang-Orang Berbeda Budaya. Editor Deddy

Ritzer, G \& Douglas J. Goodman. 2011. Teori Sosiologi Modern ; Edisi Keenam. Jakarta : Prenada Kencana Media Group.

West, R, L.H, Turner. 2008. Pengantar Teori Komunikasi : Analisis dan Aplikasi ; Buku 1, Jakarta : Salemba Humanika.

West, R, L.H, Turner. 2008. Pengantar Teori Komunikasi : Analisis dan Aplikasi; Buku 2, Jakarta : Salemba Humanika. 